Bengt Haugseth

Norges arktiske universitet

DOI: http://dx.doi.org/10.5617/adno.6992

\title{
Gehørtrening og læring
}

\section{Sammendrag}

I artikkelen presenteres en undersøkelse blant en mindre gruppe lererstudenter av utbyttet av en utbredt gehørmetode innenfor musikkundervisning. Studenter $i$ lcererutdanningen har i en årrekke fått undervisning i trinnsang for å lettere kunne lese noter og forstå melodiske mønstre. Denne undersøkelsen avdekker hvor effektiv gehørmetoden som brukes er, og hvor mye øving som skal til for å få fremgang. To studentgrupper var med i undersøkelsen. Én gruppe fikk undervisning i gehørmetoden, den andre ikke. Funn fra tidligere studier tyder på at denne metoden er effektiv i korsammenheng. Resultatene, målt gjennom pre- og posttest i notelesing og diktat, viser at lererstudenter som øver til sammen cirka 1000 minutter i en periode over 7 måneder opplever å lese noter bedre og oppfatte tonetrinn lettere.

Nøkkelord: trinnsang, notelesing, melodiforståelse, lcererstudenter

\section{Ear training and learning outcome}

\begin{abstract}
This article presents a study among a smaller group of teacher students on the outcome of a widespread ear training method used in music education. For many years, students in teacher education have learned numerical sight-singing in order to facilitate score reading and understanding of melodic patterns. This study is about measuring how effective this method is, and how much practice is required in order to attain progress. Two relatively similar student groups were included in the survey. One group had ear training, the other did not. Findings from earlier studies indicate that this method is effective in choirs. The results from this study, measured in a pre- and a post-test in score reading and melodic dictation, show that teacher students who practice around 1000 minutes over a 7month period, are more fluent and accurate in score reading and the ability to recognize melodic patterns.
\end{abstract}

Keywords: numerical sight-singing, score reading, melody recognition, teacher students 


\section{Introduksjon}

Det brukes i dag flere forskjellige systemer for å trene opp melodisk gehør og notelesingsferdigheter hos elever og studenter. De vanligste er relativ solmisasjon, absolutt solmisasjon, tonika-do og trinnsang på tall.

Man kan grovt dele overnevnte tilnærminger inn i to hovedretninger: de som alltid vil bruke navnet på den konkrete tonen som spilles, og de som plasserer tonen i forhold til den konteksten den står i (Sultanova \& Bariseri, 2012). Den første gruppen er tilhengere av å synge på tonenavn, såkalt absolutt solmisasjon, den andre av å gi tonene i en gitt skala eller toneart navn i forhold til hverandre, slik man gjør i relativ solmisasjon, tonika-do og trinnsang.

Trinnsang er kanskje den metoden som er mest utbredt i Norge. Med trinnsang menes her at man gir tallnavn til trinnene i en skala og trener på å oppfatte og diskriminere disse. Eksempelvis vil tonen D i en D-dur skala synges og oppfattes som 1, tonen E blir 2, Fiss blir 3 osv. Tanken er at man ved å sette navn på hvert trinn i skalaen, etterhvert (med letthet) vil kunne gjenkjenne melodiske vendinger, for eksempel 7-1, 5-1, 4-3, 1-6-5-7-1.

Formålet med denne studien var å teste læringseffekten av en trinntalltilnærming, det vil si hvor mye øving som skulle til for å oppleve betydelig fremgang. Det var også studiens hensikt å avdekke hva studentene syntes om denne måten å arbeide på og hvordan de øvde.

Læringseffekten av denne melodiske gehørtreningen ble testet gjennom notelesing og diktat. Det syntes hensiktsmessig å teste de to studentgruppene i både notelesing (synge et notebilde prima vista) og diktat (lytte til en melodi og skrive trinnene på denne), fordi begge disipliner er viktige aspekter i musikeres og musikklæreres hverdag. I denne studien tas det utgangspunkt i en trinntallmetodikk utviklet av Niels Eskild Johansen (Johansen, 1983, 2006). Johansens læreverk(er) har blitt brukt i gehørundervisningen i både konservatorie-, musikklinje- og folkeskoleutdanninger i Norge, i gehørundervisning i Sverige og Danmark, og dessuten i kor, korps og kulturskoler. Johansens metode er å bruke melodiske formler som utgangspunkt for en rekke øvelser. Øvelsene innenfor hvert kapittel baseres på formelen, og formlene blir stadig lengre og mer utviklet utover i læreverket. Det pedagogiske læringssynet er at jo flere melodiske mønstre og vendinger studenten blir utsatt for, jo lettere blir det å gjenkjenne og synge slike mønstre (Johansen, 2006, s. 9). Johansen bruker med andre ord en tilnærming hvor man arbeider med både helheten (toneart, formel) og enkeltdeler i lys av denne helheten, noe som er i tråd med anbefalingene som blir gitt i leseopplæring (Pressley, 2002; Stahl \& Miller, 1989; språkplan.no). 


\section{Forskning og litteratur på området}

Nilsen (2014) gjennomførte en studie i et amatørkor hvor man integrerte notelesingsundervisning (med bruk av trinntall) i korøvelsene. Nilsens konklusjon var at kormedlemmenes ferdigheter økte, samt at de også ble mer positivt innstilt til å lese noter.

En metastudie av Mishra (2016) undersøkte effekten av forskjellige metoder, eller intervensjoner, med den hensikt å forbedre melodisk og rytmisk notelesing. Etter gjennomgang av flere undersøkelser («21 studies; 35 individual analyses») mente Mishra å kunne se effekten av både trinnsang og solmisasjon/solfege: «The addition of verbal syllables, whether counting or solfege, seems to be a robust treatment that may benefit all aspects of sight reading.» (Mishra, 2016, s. 1092) I tillegg fant Mishra at det virket som om gehørtreningen hadde større effekt hos eldre elever/studenter enn hos yngre: «Also, sight reading treatments influenced older students (secondary and college) more than younger students (elementary).» Slutningen er likevel at det trengs mer forskning for at man skal kunne trekke noen konklusjoner om hvordan elever/studenter kan lære seg notelesing på best mulig måte (Mishra, 2016, s. 1090).

Kuehnes (2010) oppsummering av ti års forskning på notelesing, slår fast at det finnes flere gode metoder for å utvikle notelesing. Det viktigste ser ut til å være at lærerne hjelper elevene/studentene til å lære seg selv å løse utfordringene med notelesing, og at dette gjøres ved å holde seg til én metode og bruke denne regelmessig (Kuehne, 2010, s. 13). Videre anbefaler hun mer forskning på området, særlig i forhold til hvordan de forskjellige metodene brukes og at testenes innhold faktisk henger sammen med undervisningsinnholdet.

I en studie forsøkte Floyd \& Bradley (2006) å finne undervisningsstrategier til kordirigenter hvis kormedlemmer var dyktige til å lese noter. 24 kordirigenter ble intervjuet, og av disse oppga ingen å følge et system hvor man brukte absolutt solmisasjon, synge på tonenavn eller «nøytrale vokaler» som for eksempel a, o, å (neutral syllables). De foretrakk heller systemer som har en musikalsk funksjon, for eksempel trinnsang eller relativ solmisasjon, hvor trinnene står i forhold til hverandre. $67 \%$ av kordirigentene oppga dessuten å bruke øvelser som ikke gikk direkte på å lese noter som for eksempel ved å skrive trinn på en tavle, «peke tilfeldig» på disse trinnene (ibid., s. 76) og få kormedlemmene til å synge etter disse. Dette mener Floyd og Bradley viser at korledere med dyktige bladsangere vektlegger å styrke det auditive forholdet mellom tonene, og ikke fokuserer ensidig på å lese noter.

En norsk ph.d.-studie (Leikvoll, 2017) har undersøkt barns notelesingsferdigheter i kulturskolen. Avhandlingen tar opp relevante og viktige problemstillinger i forhold til begynneropplæring i notelesing. Siden studien dreier seg om pianoelever, fokuserer ikke Leikvoll i samme grad på å oppfatte og synge toner, fordi disse fremkommer i det eleven trykker ned tangenten på pianoet. Et indre bilde av hvordan tonen/noten høres ut, er likevel ønskelig (Leikvoll, 2017, s. 173), og 
hun trekker paralleller til moderne leseforskning hvor målet er å høre ordet for seg før det leses. Nettopp denne parallellen med å «høre for seg» melodien for sitt indre øre og sang som verktøy for å styrke dette er også vektlagt av flere musikkpedagoger og musikkforskere som Gordon (1999, 1997), McClung (2001), Blix (2013, s. 104-105, 2007, s. 70), Johansen (2007, s. 79) og Øуе (2007, s. 181).

De fleste foregående eksemplene gjelder enten voksne amatører eller barns læring i forbindelse med notelesing og gehørtrening. Blix (2013) har undersøkt musikkstudenters læringsstrategier i gehørtrening. Blix understreker at uansett hvilken lærer, hvilket innhold og hvilken metode som brukes i undervisningen, er det helt avgjørende hvordan studenten selv organiserer sin egen læring. Blix foreslår at det må oppfordres mer til at studentene reflekterer over egen læring: hvilke verktøy de bruker når de lytter, skriver og utøver, og i hvilken grad disse er tilfredsstillende. Læreren må i denne sammenheng fungere som en veileder som legger til rette for at studenten aktivt skal oppsøke råd, metoder og motivasjon (Blix, 2013, s. 112.)

\section{Metode}

I undersøkelsen ønsket jeg å avdekke hvor mye øving som skulle til for å få fremgang i notelesing og trinnoppfattelse. Det ble gjort ved å sammenlikne to studentgrupper, hvor den ene fikk undervisning i dette ukentlig, mens den andre ikke fikk spesifikk trening. Det var også ønskelig å innhente informasjon om hvordan studentene vurderte prosessen og egen læring. Undersøkelsen bruker en blanding av kvalitativ og kvantitativ metode. Det ble samlet inn kvantitative data som resultater av pre- og posttester og ukentlige øvingstider, men det ble også lagt vekt på studentenes egne refleksjoner rundt både prosessen, egen øving, denne målrettete måten å arbeide på og opplevelsen av prosjektet.

\section{Valg av design}

For å undersøke læringseffekten av å øve på notelesing og trinnoppfattelse ble et eksperimentelt design valgt. Én studentgruppe ble utsatt for eksperimentet mens den andre studentgruppen ikke fikk denne påvirkningen. Et eksperimentelt design er hensiktsmessig hvis man vil teste ut effekten av et bestemt opplegg eller en metode (Lund \& Haugen, 2006, s. 129). Et ekte eksperimentelt design innebærer en intervensjon, der forskeren selv påvirker årsaksfaktoren, og der gruppeinndelingen skal være tilfeldig (Lund \& Haugen, 2006, s. 128). Noen ganger er det umulig å etterkomme kravene til ekte eksperimentelt design, og det var tilfellet i denne studien. De to studentgruppene i eksperimentet var etablerte studentklasser som ikke kunne forandres på grunn av ulike fagkombinasjoner. Gruppeinndelingen var derfor ikke tilfeldig. Designet i denne undersøkelsen ble dermed kvasieksperimentelt. Kvasieksperimentelt design er likt eksperimentelt design ved 
at man gjennomfører en intervensjon, men skiller seg fra den fordi gruppene i undersøkelsen ikke er tilfeldig utvalgte (Kleven, 2002, s. 153-154).

De to studentklassene ble i utgangspunktet vurdert som relativt like ut fra studentenes bakgrunn i kor/korps/band. Pretesten viste likevel at de ikke var så like som forventet.

\section{Tolkning av prima vista-sang}

I vurderingen av pre- og posttest ble det fokusert på antall korrekte trinn, ikke på enkeltintervaller. Notelesingstesten gikk i dur, og korrekt trinnrekke var 5-1-2-32-1-2-5-4-3-2-1-2-7-1 (se figur 1). Studentene måtte treffe disse trinnene for å oppnå full skår på testen. Hvis studentene sang lavt 3. trinn (moll), ble det vurdert som feil. Det ble ikke trukket for rytmiske feil.

\section{Valg av forsøkspersoner}

Det ble valgt ut to studentgrupper i universitetets lærerutdanning som hadde musikk som 30 studiepoengs emne hvor fokuset var rettet mot musikkdidaktikk i grunnskolen. Alle studentene takket ja til å være med på undersøkelsen. Eksperimentgruppen inneholdt 8 studenter og kontrollgruppen 8 studenter.

Gruppene ble valgt fordi de ble oppfattet som relativt like. Alle studentene hadde en eller annen form for musikkbakgrunn som for eksempel kor, korps, band, musikklinje og/eller kulturskole.

\section{Valg av måleinstrument}

Pretestens melodirekker fremgår av figur 1:

Notelesing:

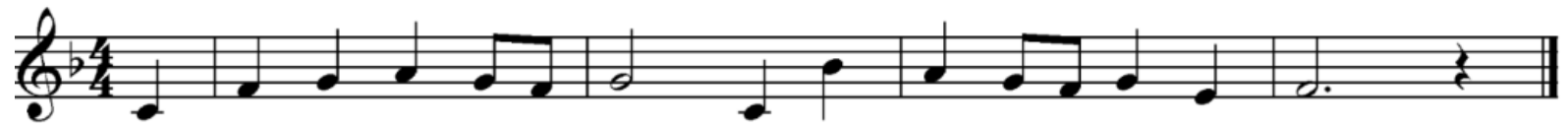

Diktat:

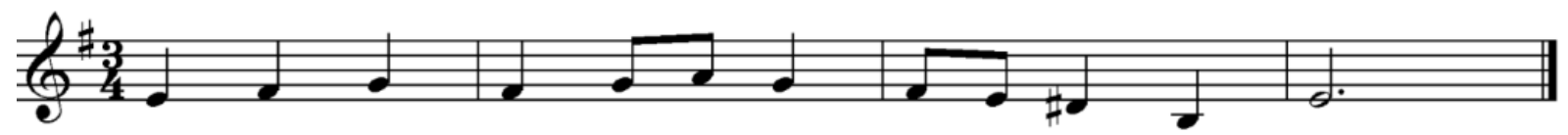

Figur 1. Notelesing og diktat

Notelesingstesten var en enkel notelinje på fire takter skrevet på notasjonsprogrammet Sibelius, standard noteskrift. Studentene fikk cirka 10 sekunder på å skaffe seg en oversikt, og ble så bedt om å synge melodien uten hjelp av puls/opptelling eller melodiske hint. I tillegg skulle studentene skrive ned trinnene på en melodi spilt på piano. Ved posttestene ble de samme melodiene brukt, men transponert til andre tonearter enn pretestene: D-dur for notelesing, D-moll for diktat. Det ble gjort opptak av studentenes sang i pre- og posttest. 


\section{Poeng}

Pre- og posttest ble bedømt ved bruk av poeng. Jo høyere treffprosent på tonene, jo høyere tall. Maksimal poengsum på notelesingstesten var gi 15 poeng for 15 korrekte toner, og på diktattesten maksimalt 12 poeng for 12 korrekte toner.

\section{Gjennomføring}

Eksperimentgruppen fikk ukentlig undervisning i trinnsang, notelesing og diktat. Kontrollgruppen fikk ikke spesifikk trening i dette.

Prosjektet startet og sluttet med en test i notelesing og diktat. Pretesten ble gjennomført i september 2014, posttesten i april 2015. Fordi perioden mellom de to testene var relativt lang (7 måneder), valgte man å legge posttesten til en annen toneart, men ellers la trinnene være uendret. Grunnen til dette var at man da kunne få målt spesifikke melodiske mønstre og hvorvidt disse ble forbedret ved posttesting. Studentene fikk ikke vite at pre- og posttest var trinnvis identiske.

Fordi begge gruppene hadde en del musikkerfaring, men samtidig oppga å ha lite ferdigheter med tanke på notelesing og trinnoppfattelse, ble det bestemt at en pretest som går opp til skalaens 4. trinn og ned til 5. (uten bruk av 6. trinn) var passende. Det var viktig å ikke lage testen for lett, fordi det - med god skår for alle deltakerne - ville være vanskelig å dokumentere fremgang. På den annen side ville det være uheldig hvis testen var for utfordrende, fordi det da ville være vanskelig å se forskjeller mellom studentene.

Testen for notelesing ble gjennomført ved at studentene ble tatt inn på musikkrommet én og én, og fikk utlevert melodien de skulle synge. Etter cirka 10 sekunder skulle de synge melodien uten hjelp av oppgitt grunntone, akkorder eller kadenser. Mange bar preg av å lese melodien "grafisk», det vil si at de kunne se om melodien gikk opp eller ned og de kunne se forskjell på store og små sprang. Imidlertid hadde de ikke alltid kontroll på hvilket trinn de var på, noe som førte til at flere fikk lav skår på pretesten. Testen for diktat ble utført ved at studentene skulle skrive ned trinnene på en melodi spilt på piano. Måten de skulle notere på (1. skalatrinn $=1$, 2. skalatrinn $=2$ osv.), ble forklart før testen startet. Testen ble utført på et musikkrom og studentene satt med god avstand til hverandre.

Etter at pretestene var avsluttet fortsatte kontrollgruppen med aktiviteter rettet mot musikkundervisning i skolen: Sang, bevegelsesaktiviteter, samspill, komposisjon, arrangering, didaktisk tilrettelegging for barn i skolealder m.m. Flere av disse aktivitetene innebar notelesing, men gruppen fikk ikke spesifikk trening i gehør og notelesing tilsvarende eksperimentgruppen.

Gjennom forsøksperioden skulle alle studentene i eksperimentgruppen føre øvingslogg. Det ble understreket at øvingsmengden var opp til hver student, der lite øvingstid ikke hadde konsekvenser for studiet. Det som imidlertid var viktig, var at alle førte logg så korrekt som mulig. For å sikre at ikke studentene skulle glemme å føre logg, ble det innsamlet loggdata hver undervisningsuke. Det ble 
også opprettet en gruppe på Messenger hvor studentene ble påminnet å skrive logg.

Det ble satt av 2 undervisningstimer - en dobbelttime - i uka til undervisning med utgangspunkt i Johansens (2006) læreverk. Resten av tida var det opp til studentene hvor mye tid de ville bruke til øving.

I undervisningstimene ble det lagt vekt på varierende arbeidsmåter for å tydeliggjøre Johansens helhet/del-metodikk forklart tidligere. Studentene skulle trenes i å etablere en grunntone og så finne formelen ut fra denne. Når en formel på for eksempel 1-2-3-4-3-2-1-7-1 i dur var etablert, øvde man seg på å synge den samme formelen i flere tonearter. Når studentene følte seg komfortable med å etablere grunntone og formel, fikk de forsøke å lage små melodier innenfor formelen, og de fikk prøve å lese et notebilde basert på formelen. En viktig arbeidsoppgave var da å finne tonearten, etablere en grunntone og synge en formel før man prøvde å synge notebildet. Det ble arbeidet mye med å «høre for seg» melodiene for sitt indre øre, en tilnærming som, tidligere nevnt, mange gehørpedagoger vektlegger. Følgende arbeidsmåter ble brukt: A) varme opp ved at gruppen står i ring og sammen synger en av formlene i flere tonearter, B) lærer synger små melodier basert på formelen, eksempelvis 1-3-4-7-1, og studentene repeterer, C) lærer synger små melodier basert på formelen, men ikke på trinntall (på «la-la», «ro-ro» etc.). Så skal studentene gjenta ved å synge den samme melodien på trinntall. Etter hvert som studentene ble vant til å arbeide på denne måten, ble det også innført at D) hver student prøver å lage en enkel melodi som de andre skal gjengi, E) lærer spiller små melodier på pianoet som studenter prøver å gjengi, og F) studentene skriver ned små melodier som trinn eller noter. Mesteparten av tida ble brukt på G) å synge melodiske øvelser fra Johansens læreverk.

På slutten av perioden hendte det at man gjorde noen øvelser sammen, og deretter delte opp gruppen slik at alle fikk arbeide med de delene av metodeverket som var mest hensiktsmessig for dem.

Etter posttesten ble det gjennomført et skriftlig intervju med eksperimentgruppen. Temaene var blant annet om dette prosjektet var relevant i utdanningen, om det var relevant for å kunne utvikle seg som musiker, og hvordan studentene gikk frem når de øvde.

\section{Etiske vurderinger}

Prosjektet ble meldt inn til Norsk senter for forskningsdata (NSD). Testene ble så anonymisert ved å gi hver student en bokstav (eksperimentgruppe) eller et tall (kontrollgruppe). Alle studentene i studien underskrev samtykkeskjema. Det var noen etiske betenkeligheter med denne type gjennomføring, da kontrollgruppen ikke fikk samme type oppfølging som eksperimentgruppen med hensyn til 
notelesing og diktat. Dette ble likevel vurdert som faglig forsvarlig siden kontrollgruppen fikk muligheten til å fokusere på andre aspekter ved musikkfaget.

\section{Resultater}

Resultatene for eksperiment- og kontrollgruppen oppgis både i antall og prosentvis riktig leste noter og nedskrevne trinn, jf. nedenstående tabeller 1 og 2.

\section{Notelesing}

Tabell 1. Eksperimentgruppens og kontrollgruppens skår på notelesing (antall korrekte noter).

\begin{tabular}{|c|c|c|c|c|c|}
\hline \multicolumn{3}{|c|}{ Eksperimentgruppen } & \multicolumn{3}{|c|}{ Kontrollgruppen } \\
\hline Student & Pretest & Posttest & Student & Pretest & Posttest \\
\hline A & 4 av $15(27 \%)$ & 15 av $15(100 \%)$ & 1 & 3 av $15(20 \%)$ & 1 av 15 (7\%) \\
\hline B & 4 av $15(27 \%)$ & 15 av $15(100 \%)$ & 2 & 1 av 15 (7\%) & 1 av 15 (7 \%) \\
\hline $\mathrm{C}$ & 12 av $15(80 \%)$ & 9 av $15 \quad(60 \%)$ & 3 & 1 av $15(7 \%)$ & 1 av 15 (7\%) \\
\hline $\mathrm{D}$ & 12 av $15(80 \%)$ & 15 av $15(100 \%)$ & 4 & 14 av $15(93 \%)$ & 14 av 15 (93 \%) \\
\hline $\mathrm{E}$ & 6 av $15(40 \%)$ & 15 av $15(100 \%)$ & 5 & 3 av $15(20 \%)$ & 7 av $15(47 \%)$ \\
\hline $\mathrm{F}$ & 7 av 15 (47 \%) & 15 av $15(100 \%)$ & 6 & 0 av $15 \quad(0 \%)$ & 1 av 15 (7\%) \\
\hline$G$ & 5 av $15(33 \%)$ & 15 av $15(100 \%)$ & 7 & ikke gjennomført & ikke gjennomført \\
\hline $\mathrm{H}$ & 10 av 15 (67 \%) & 15 av $15(100 \%)$ & 8 & 1 av $15 \quad(7 \%)$ & 7 av 15 (47 \%) \\
\hline
\end{tabular}

Tabell 2. Eksperiment- og kontrollgruppens gjennomsnittlige skår (M) på notelesing.

\begin{tabular}{|l|l|l|l|}
\hline & M pretest & M posttest & $\begin{array}{l}\text { Økning fra pretest til posttest } \\
\text { (prosentpoeng) }\end{array}$ \\
\hline Eksperimentgruppen & $50,0 \%$ & $95,0 \%$ & 45,0 \\
\hline Kontrollgruppen & $21,9 \%$ & $30,5 \%$ & 8,6 \\
\hline
\end{tabular}

Ut fra tabell 2 ser vi at eksperimentgruppens samlede resultat ble markant bedre fra pre- til posttest, med en gjennomsnittlig økning på 45 prosentpoeng. Tabell 1 viser at alle studentene i eksperimentgruppen bortsett fra $\mathrm{C}$ hadde fremgang fra pre- til posttest. Det at sju av åtte studenter fikk full skår på posttesten, indikerer at de antakelig kunne mestret mer avanserte notelesingsoppgaver.

Tabell 2 viser at kontrollgruppen samlet hadde en fremgang på 8,6 prosentpoeng fra pre- til posttest i notelesing. Denne fremgangen er beskjeden i forhold til eksperimentgruppen. Resultatene for kontrollgruppen i tabell 1 viser at student 1 klarte to færre toner enn ved pretesten, student 6 traff én mindre, studentene 2, 3 og 4 hadde samme resultat, mens studentene 5 og 8 viste god fremgang.

\section{Oppsummering av notelesingskår}

Resultatene fra tabellene 1 og 2 viser en betydelig forskjell mellom eksperimentgruppen og kontrollgruppen når det gjelder forbedring fra pretesten til posttesten. Forskjellen mellom gruppene er 36,4 prosentpoeng, noe som kan indikere en sannsynlig effekt av øving. Det var ett unntak i eksperimentgruppen, student C. Dette diskuteres senere under avsnittet om øvingslogg. 


\section{Diktat}

Tabell 3. Eksperiment- og kontrollgruppens skår på diktat.

\begin{tabular}{|l|r|r|l|l|r|}
\hline \multicolumn{2}{|l|}{ Eksperimentgruppen } & Kontrollgruppen \\
\hline Student & Pre-test & Post-test & Student & Pre-test & Post-test \\
\hline A & 4 av $12(33 \%)$ & 9 av $12(75 \%)$ & 1 & 5 av $12 \quad(42 \%)$ & 9 av $12 \quad(75 \%)$ \\
\hline B & 6 av $12(50 \%)$ & 12 av $12(100 \%)$ & 2 & 8 av $12(67 \%)$ & 7 av $12(58 \%)$ \\
\hline C & 9 av $12(75 \%)$ & 12 av $12(100 \%)$ & 3 & 8 av $12(67 \%)$ & 12 av $12(100 \%)$ \\
\hline D & 12 av $12(100 \%)$ & 12 av $12(100 \%)$ & 4 & 12 av $12(100 \%)$ & 12 av $12(100 \%)$ \\
\hline E & 12 av $12(100 \%)$ & 12 av $12(100 \%)$ & 5 & 11 av $12(92 \%)$ & 12 av $12(100 \%)$ \\
\hline F & 5 av $12(42 \%)$ & 10 av $12(83 \%)$ & 6 & 8 av $12(67 \%)$ & 9 av $12(75 \%)$ \\
\hline G & 12 av $12(100 \%)$ & 12 av $12(100 \%)$ & 7 & 11 av $12(92 \%)$ & 12 av $12(100 \%)$ \\
\hline H & 10 av $12(83 \%)$ & 12 av $12(100 \%)$ & 8 & 6 av $12 \quad(50 \%)$ & 8 av $12(67 \%)$ \\
\hline
\end{tabular}

Tabell 4. Eksperiment- og kontrollgruppens gjennomsnittlige skår (M) på diktat.

\begin{tabular}{|l|l|l|l|}
\hline & M pretest & M posttest & $\begin{array}{l}\text { Økning fra pretest til posttest } \\
\text { (prosentpoeng) }\end{array}$ \\
\hline Eksperimentgruppen & $72,9 \%$ & $94,8 \%$ & 21,9 \\
\hline Kontrollgruppen & $71,9 \%$ & $84,4 \%$ & 12,5 \\
\hline
\end{tabular}

Tabell 4 viser at studentene i eksperimentgruppen gjorde det bedre på posttesten i diktat, med en gjennomsnittlig økning på 21,9 prosentpoeng.

Også studentene i kontrollgruppen gjorde det bedre på posttesten i diktat, bortsett fra student 2 som oppfattet én tone mindre på posttesten (jf. tabell 3). Gruppen klarte 12 flere toner enn de gjorde på pretesten, en økning på 12,5 prosentpoeng.

\section{Oppsummering av diktatskår}

Resultatene fra tabellene 3 og 4 viser en økning i begge gruppene. Forskjellen mellom gruppene er ikke like betydelig som ved notelesingstesten. Det høye antallet studenter med full skår i eksperimentgruppen (6 av 8 studenter) tyder imidlertid på at flere kunne klart en mer utfordrende test, og at posttesten dermed ikke gir et tydelig bilde av studentenes utvikling.

\section{Resultater fra øvingslogg}

Tabell 5. Utdrag fra studentenes øvingslogg (øvingstid i minutter).

\begin{tabular}{|l|l|l|l|l|}
\hline Student & Uke 41/42 & Uke 42/43 & Uke 43/44 & Uke 44/45 \\
\hline A & 0 & $30+15+20$ & 0 & 0 \\
\hline B & $4 \times 15+10$ & 15 & $30+15$ & $7 \times 15$ \\
\hline C & $2 \times 10$ & 0 & 0 & Tils. 20 \\
\hline D & $3 \times 10$ & $2 \times 15+10$ & $3 \times 10+5$ & $2 \times 10+15$ \\
\hline E & $2 \times 10+15$ & 15 & 0 & 0 \\
\hline F & $10+12+5$ & $2 \times 5+10+30$ & 30 & 10 \\
\hline G & 15 & $5+10$ & $15+10$ & $2 \times 15+10$ \\
\hline H & $5 \times 10$ & $2 \times 10$ & 10 & $4 \times 10$ \\
\hline
\end{tabular}

Når det gjelder øvingshyppighet og volum, altså om man for eksempel velger å øve lite og ofte eller mye og sjeldent, viser det seg at de fleste studentene valgte å 
øve relativt ofte og ikke lengre enn $30 \mathrm{~min}$. Et utdrag fra øvingsloggene for ukene 41-45 illustrerer dette, jf. tabell 5.

Hvis vi ser studentenes øving i forhold til posttestresultat, kan man se en tydelig fremgang på de fleste. 7 av 8 studenter i eksperimentgruppen viste stor fremgang i notelesing fra prosjektets start i september til posttesten i april. Det var ett unntak: C var studenten med minst øvingstid (295 minutters egenøving i løpet av en periode på 7 måneder). $\mathrm{C}$ hadde på notelesing en tilbakegang fra pretil posttest, fra 12 av 15 korrekte noter, til 9 av 15 (på diktat hadde $C$ en tilsvarende fremgang, fra 9 av 12 til 12 av 12). I diktat hadde studentene tydelig fremgang (eller samme resultat hvis resultatet på pretesten var 12 av 12 mulige toner).

5 minutter øving om dagen i 7 måneder gir en samlet øvingsmengde på cirka 1000 minutter $(5 \times 30 \times 7=1050)$ og studentene $\mathrm{B}, \mathrm{D}, \mathrm{E}, \mathrm{F}$ og $\mathrm{H}$ lå alle i dette sjiktet (815-1588 minutter). Til og med A og G med henholdsvis 430 og 630 minutter øving viste betydelig fremgang.

\section{Reliabilitet og validitet}

I forhold til validitet kan noe av kritikken være at man i dette prosjektet testet studentene utelukkende i dur- og mollmelodier. Lærestoffet var også nesten utelukkende dur og harmonisk og melodisk moll. I dagens musikkultur eksponeres man for flere typer tonalitet (modale tonearter, bluesskala, pentatonikk m.m.) og dessuten bi- og atonalitet. På den ene siden kan man si at prosjektet bare har bidratt til trinnoppfattelse og notelesingsferdigheter i dur og moll og ikke passer til andre sjangre og tonaliteter. På en annen side kan man hevde at trinnforståelse i dur og moll legger et godt grunnlag for videre arbeid og forståelse av andre typer tonalitet.

Noe som svekker reliabiliteten, er at antallet forsøkspersoner i undersøkelsen ikke er stort nok til at det kan trekkes noen klare slutninger om hvor mye trening som skal til for å styrke gehøret. Studien kan likevel gi en indikasjon på at få minutter øving hver dag over tid kan gi god effekt.

Noen studenter trengte flere påminnelser for loggskriving. Det kan ikke utelukkes at studentene oppga feil øvingstid, enten fordi de hadde glemt hvor mye de hadde øvd, eller for at de ville virke flinke.

Testene kan ha blitt forstyrret av nervøsitet hos studentene. I slike testsituasjoner er det mange som blir usikre. Ved pretesten oppga flere studenter at det var overraskende at et såpass enkelt notebilde ble så vanskelig å synge uten hjelpemidler, noe som må ha føltes stressende. Det kan tenkes at studentene ble roligere andre gang de skulle testes, fordi de da visste hva de skulle igjennom og kjente situasjonen. Det kan ikke utelukkes at trening og forberedelser gjennom (nesten) et helt studieår i seg selv gjorde at studentene ble mer komfortable med situasjonen og dermed presterte bedre. Likevel kan det være rimelig å anta at de forbedrete resultatene var forankret i en økt faglig trygghet. Som student E sier det: «Det føles veldig enkelt nå i forhold til da vi begynte. Er som sagt blitt veldig trygg på å finne grunntonen og vite hvor tonene/trinnene ligger i forhold til hverandre.» 
På den annen side følte nok flere et visst press da det nærmet seg posttest. Når det øvdes målrettet i månedsvis, kan enkelte ha fått følelsen av å «måtte lykkes». I intervjuene i etterkant av undersøkelsen trakk flere av studentene frem lærerens entusiasme. Dette kan spille både positivt og negativt inn for validiteten av undersøkelsen. En entusiastisk lærer kan lett føre til at studentene synes prosjektet er viktig for at læreren skal lykkes med noe, ikke fordi dette kan fortelle dem noe om utvikling og testing av læremetoder eller opptrening av gehør. I tillegg kan en lærer med stor entusiasme også skape forventninger og fremkalle stress i forhold til at studentene føler de må prestere på testene.

\section{Diskusjon}

Siden ingen av kandidatene hadde absolutt gehør, ble melodien på pre- og posttest som regel sunget i en annen toneart enn den som var notert, og det måtte dermed fokuseres på om studenten hadde truffet de korrekte trinnene. Riktig trinnrekke i notelesing var 5-1-2-3-2-1-2-5-4-3-2-1-2-7-1, altså maksimalt 15 korrekte toner. En av studentene sang mollters istedenfor durters og fikk ikke poeng for dette trinnet. Vurderingen av studentenes prima vista-sang var til tider krevende. Noen studenter kunne muligens ha fått høyere skår hvis man hadde målt enkeltintervaller, men hvis studenten «forlater» tonearten og bare satser på enkeltintervaller, gir notelesing, i hvert fall tonal notelesing, lite mening. Derfor bruktes en vurderingstilnærming hvor det fokuseres på antall riktige trinn innenfor en etablert toneart. Noen ganger var melodien som ble sunget langt fra å likne noteeksemplet, det var lite spor av tonalitet og/eller grunntonefølelse. Disse studentene fikk da 1 eller 0 poeng. Vurderingsmetoden illustreres i følgende 3 eksempler:

En av studentene som hadde høy skår i pretesten, var kontrollgruppens student 4. Denne studenten fikk 14 av 15 korrekte trinn. Her følger en transkripsjon av denne studentens bladsang, hvor man kan se at B-en, siste firedel i 2.takt, er sunget feil, men at studenten korrekt identifiserer 3.trinn i neste takt, jf. figur 2:

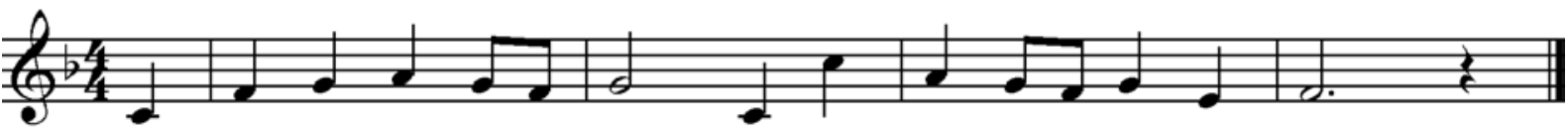

Figur 2. Bladsang i pretesten, student 4.

Eksperimentgruppens student $\mathrm{H}$ hadde 10 korrekte trinn, jf. figur 3:

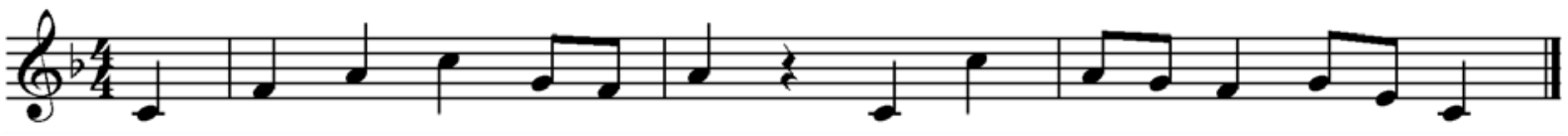

Figur 3. Bladsang i pretesten, student $\mathrm{H}$.

Student $\mathrm{H}$ holdt tonaliteten fra start til slutt, men bommet på en del trinn. Rytmiske feil førte ikke til trekk. 
Student 1 fra kontrollgruppen fikk 3 korrekte trinn, de tre første tonene i melodien. Deretter mistet studenten tonalitetsfølelsen, jf. figur 4:

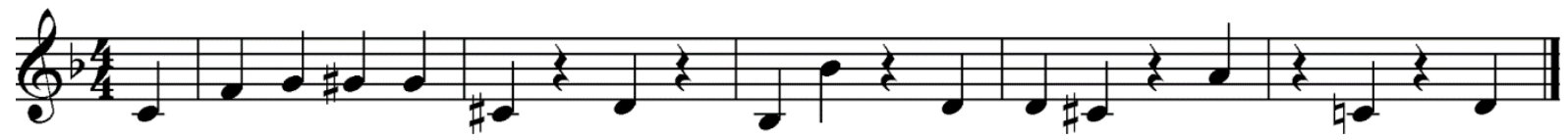

Figur 4. Bladsang i pretesten, student 1.

I overgangen mellom takt én og to kan man se et kvintintervall og argumentere for at dette er trinn 2 ned til 5, men siden studenten har «forlatt» tonearten (og den dypeste tonen kommer i takt 3), ble det vurdert som feil.

En tydelig forskjell fra pre- til posttest var at eksperimentgruppen behersket å tenke helhet, det vil si at de tok seg tid til å se på toneart og tenke formel før de startet å synge. Pretesten var preget av at flere gikk fra note til note og «gamblet» på at intervallene ble korrekte. Dette ble særlig tydelig i spranget fra 5. trinn under grunntonen til 4. trinn over grunntonen, som ingen behersket i pretesten, men som 7 av 8 studenter i eksperimentgruppen klarte 7 måneder senere. Dette indikerer at «formelmetoden» til Johansen har god effekt innenfor tonal notelesing.

Da undervisningen startet, ble det tidlig klart at noen studenter tilegnet seg nytt stoff fortere enn andre. Tre av studentene hadde høy motivasjon, noe som kan ha virket positivt på læringen. En sang i kor og hadde stor interesse av å lære seg å lese noter bedre, en hadde planer om å ta opptaksprøve til et musikkonservatorium og en var svært interessert i pianospilling og notelesing. I tillegg var det forskjeller i studentenes øvingstid (fra 295 til 1588 minutt i løpet av 7 måneder). I ettertid kan det tenkes at en nivådeling tidligere i undervisningsforløpet hadde ført til bedre resultater.

Pretesten viste en betydelig forskjell mellom kontrollgruppen og eksperimentgruppen i notelesing (eksperimentgruppen skåret høyere). Dette kan indikere at forutsetningene for å lære seg notelesing var bedre for eksperimentgruppen, og at man derfor skal være forsiktig med å trekke klare konklusjoner.

Sett i lys av funnene til Kuehne (2010) kunne man kanskje lagt enda mer vekt på studentens egenøving i dette prosjektet, noe som også fremkommer av intervjuene i etterkant. Studentenes tilbakemeldinger i etterkant av studien tyder på at metodikken når man øver alene har vært problematisert i for liten grad. Flere av studentene oppgir å ha sunget «etter boka», uten at man helt vet hva dette innebærer. Det kan tenkes at det øves/synges uten bevisstgjøring på fremgangsmåte, selv om flere hevder å ha brukt formeltenkning som utgangspunkt for notelesing. Hvis man støtter seg til et instrument, som noen også hevder å ha gjort, kan det være at dette hindrer læreprosessen fordi studenten korrigerer seg selv hele tiden og dermed ikke får trent skikkelig på å klare seg uten hjelpemidler.

Flere av studentene understreket $\mathrm{i}$ etterkant at de var mer positive til notelesing (som kormedlemmene i Nilsens (2014) undersøkelse), at de satte pris på å ha et tydelig læringsmål mange måneder frem i tid, og på å kunne jobbe systematisk mot dette målet. En slik fremgangsmåte kan sammenliknes med Biggs’ (1999) 
«Constructive alignment» i høyere utdanning, og indikerer at dette er noe å bygge videre på for at studentene skal oppfatte undervisningen som meningsfull. Undersøkelsen samsvarer med funnene i Mishras (2016) metastudie, ved at studentene i etterkant mente at trinntallstenkning hadde hjulpet dem til å forstå noter bedre. Som student A uttrykker det: «Jeg hadde liten eller ingen forståelse av noter og notesystemet før jeg begynte i fjor. Trinnlesingen har hjulpet meg med å få bedre gehør og med å kunne se en melodi på notearket og høre den i hodet.» Mishras påstand om at slike metoder (sight reading treatments) kan passe bedre til eldre studenter enn barn, skal ikke diskuteres inngående, men det hjalp nok studentene i eksperimentgruppen at de forsto grunnleggende musikkteori og dermed kunne identifisere tonearter ved et raskt blikk på notebildet.

I løpet av prosjektperioden ble det forsøkt å fokusere på funnene fra Floyd \& Bradley (2006), og anbefalingene fra Gordon (1997, 1999), McClung (2001), Blix (2007, 2013), Johansen (2007) og Øye (2007), ved at studentene måtte arbeide aktivt med å «høre for seg» trinnene og skape melodier løsrevet fra et notebilde. Denne styrkingen av det auditive, indre bildet, ble også understreket som positivt av studentene i intervjuene i etterkant av prosjektet. I prosjektperioden ble det brukt mest tid på notelesing. I videre studier kan det vurderes å bruke enda mer tid på trening uten noter for å få styrket et slikt indre bilde.

\section{Konklusjon}

Ser man på øvingstid i forhold til resultat, kan en forsiktig konklusjon være at så lite som 5 minutter øving om dagen over en periode på cirka et halvt år kan være nok til å registrere en betydelig fremgang i notelesing og diktat hos studenter. Sang/spill etter noter, men lite spesifikt arbeid med notelesing (kontrollgruppe) og spesifikk undervisning, men lite øving (student C) ser ut til å være utilstrekkelig for å få fremgang. Likevel må det flere liknende undersøkelser til, og gjerne med betydelig større grupper, før sikrere slutninger kan trekkes. Ut fra tilbakemeldingene fra studentene bør det dessuten fokuseres mer på hvordan studenter organiserer sin egen læring når de øver på å utvikle gehøret, noe Blix (2013) som nevnt innledningsvis også anbefaler.

I etterkant av denne intervensjonen følte studentene at de behersket noe som før hadde vært vanskelig, og det å skape slike læringsopplevelser kan legge et grunnlag for økt selvtillit, nysgjerrighet og motivasjon for videre læring.

\section{Om forfatteren}

Bengt Haugseth er universitetslektor i musikkpedagogikk. Hans faglige interesseområder: gehørdidaktikk, musikk og bevegelse, tverrfaglige prosjekter, dokumentasjon i musikkfaget, sammenheng mellom undervisningsinnhold og eksamen, 
studentinvolvering, samarbeid med praksisfeltet, vurdering i musikkfaget, kritisk tenkning i skole og høyere utdanning.

Institusjonstilknytning: Musikkkonservatoriet, Norges arktiske universitet, UiT, 9006 Tromsø.

E-post: bengt.haugseth@uit.no

\section{Referanser}

Biggs, J. (1999). What the Student Does: Teaching for enhanced learning. Higher Education Research \& Development, 18(1), 57-75. doi: https://doi.org/10.1080/0729436990180105

Blix, H. S. (2007). Om å lese noter. I H. S. Blix \& A. K. Bergby (red.), Øre for musikk. Om å undervise i hørelcre (s. 60-74). Oslo: Uniped.

Blix, H. S. (2013). Learning strategies in ear training. I I. E. Reitan, A. K. Bergby, V. Jakhelln, G. Shetelig \& I. F. Øye (red.) Aural Perspectives. On Musical Learning and Practice in Higher Music Education (s. 97-115). Oslo: NMH-Publikasjoner 2013:10.

Floyd, E. \& Bradley, K. D. (2006). Teaching Strategies Related to Successful Sight-Singing in Kentucky Choral Ensembles. Update: Applications of Research in Music Education, 25(1), 70-81.

Gordon, E. E. (1997). Learning sequences in music: A music learning theory. Chicago: GIA Publications.

Gordon, E. E. (1999). All About Audiation and Music Aptitudes. Music Educators Journal, September, 41-44. doi: http://journals.sagepub.com/doi/pdf/10.2307/3399589

Johansen, N. E. (2007). Melodi. I H. S. Blix \& A. K. Bergby (red.), Øre for musikk. Om å undervise i hørelcere (s. 77-93). Oslo: Unipub.

Johansen, N. E. (2006). Hørelære. Med på notene. Oslo: Norsk musikforlag a/s.

Johansen, N. E. (1983). Hørelære. Melodi i dur og moll. Oslo: Norsk musikforlag a/s.

Kleven, T. A. (red.) (2002). Innføring i pedagogisk forskningsmetode. En hjelp til kritisk tolkning og vurdering. Fagbokforlaget, Bergen.

Kuehne, J. M. (2010). Sight-Singing: Ten Years of Published Research. Update: Applications of Research in Music Education, 29(1), 7-14.

Leikvoll, J. K. (2017). Lytt, skriv, spill: Om notelesingsferdigheter hos pianoelever på nybegynnernivå. Doktoravhandling, Institutt for musikk og dans, Universitetet i Stavanger.

Lund, T. \& Haugen, R. (2006). Forskningsprossesen. Oslo: Unipub a/s.

McClung, A. C. (2001). Sight-Singing Systems: Current Practice and Survey of All-State Choristers. Update: Applications of Research in Music Education, 20(1), 3-8.

Mishra, J. (2016). Rhythmic and melodic sight reading interventions: Two meta-analyses. Psychology of Music, 44(5), 1082-1094. doi: http://journals.sagepub.com/doi/pdf/10.1177/0305735615610925

Nilsen, B. A. (2014). Notelesingsundervisning integrert i amatørkorprøver. Masteroppgave, UiT - Norges arktiske universitet.

Pressley, M. (2002). Effective Beginning Reading Instruction. Journal of Literacy Research, 34(2), 165-188, doi: http://journals.sagepub.com/doi/pdf/10.1207/s15548430jlr3402__

Språkplan.no. Komponenter i god begynneropplering. Hentet fra: http://sprakplan.no/komponenter-i-god-begynneropplaering/

Stahl S. A. \& Miller P. D. (1989). Whole Language and Language Experience Approaches for Beginning Reading: A Quantitative Research Synthesis. Review of Educational Research, 59(1), 87-116. doi: http://journals.sagepub.com/doi/pdf/10.3102/00346543059001087 
Sultanova, A. \& Bariseri, N. (2012). Conjectural and absolute solmization systems in music. Procedia - Social and Behavioral Sciences, 46, 2394-2397. Hentet fra: https://www.sciencedirect.com/science/article/pii/S1877042812016205

Øye, I. F. (2007). Gehørarbeid i instrumentalundervisningen. I H. S. Blix \& A. K. Bergby (red.), Øre for musikk. Om å undervise i hørelcre (s. 179-192). Oslo: Unipub. 